
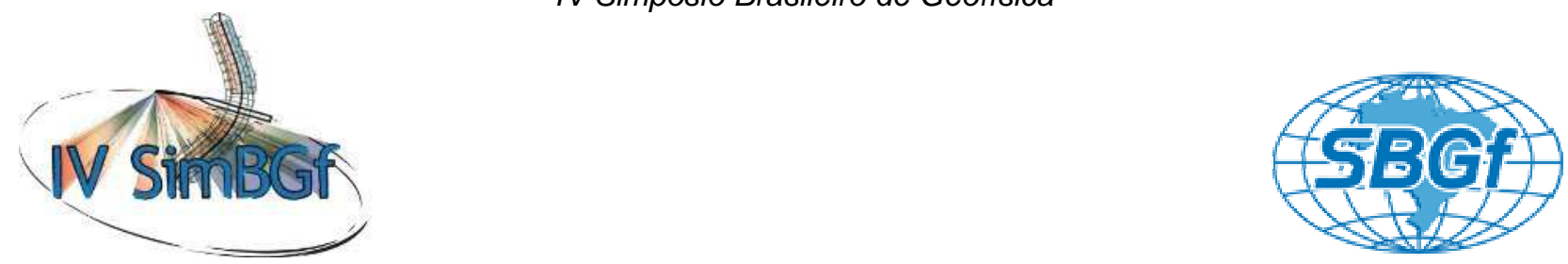

\title{
Airborne geophysics applied to the detection of microseepages in Remanso do Fogo area, San Francisco Basin
}

Julia Barbosa Curto*1 - julia.curto@gmail.com

Augusto César Bittencourt Pires ${ }^{1}$, Adalene Moreira Silva ${ }^{1}$ and Álvaro Penteado Crósta ${ }^{2}$

${ }^{1}$ University of Brasília and ${ }^{2}$ State University of Campinas

Copyright 2010, SBGf - Sociedade Brasileira de Geofísica

Este texto foi preparado para a apresentação no IV Simpósio Brasileiro de Geofísica, Brasília, 14 a 17 de novembro de 2010. Seu conteúdo foi revisado pelo Comitê Técnico do IV SimBGf, mas não necessariamente representa a opinião da SBGf ou de seus associados. E proibida a reprodução total ou parcial deste material para propósitos comerciais sem prévia autorização da SBG.

\section{Resume}

Some attributes of areas affected by light hydrocarbon microseepages are: potassium depletion and magnetic signatures associated with near-surface structures and diagenetic magnetic minerals. Therefore, this study used geophysical data to indentify these indicators in Remanso do Fogo area, San Francisco Basin.

Technical procedures were applied to minimize the contribution by the presence of recent sediments coverage and deeper magnetic signatures, in radiometric and magnetic data, respectively. The gamma-ray spectrometry data were normalized by thorium and yielded low residual potassium estimates. In the magnetic data, the amplitude of analytic signal of the anomalous magnetic field, using the second derivatives, was the main product to interpret shallow lineaments. These lineaments can represent possible gas pathways.

The main geophysical products were integrated using fuzzy logic classification. Most of the results have spatial correspondence with the registered occurrences of gas and the iso-concentration curves of light hydrocarbons obtained by the Petrobrás geochemical campaign in 1987.

\section{Introduction}

The development of high-resolution aerogeophysics has allowed new possibilities for the exploration surveys on the oil industry. Seismic reflection and well logging methods are the most precise geophysical tools applied in the definition of petroleum systems, but data acquisition with these methods is costlier, which limits their utilization. Therefore, it is important to use other indirect techniques to reduce the areas to be investigated and increase the probability of success. Because of this, the detection of microseepages by indirect methods has become an important variable for hydrocarbon exploration (Saunders et al. 1993, LeShack \& Van Alstine 2002).

Hydrocarbon microseepage is commonly explained as the result of vertical ascent of colloidal gas bubbles of light hydrocarbons through water filled networks of fractures, joints, and bedding planes within overlying formations
(Saunders et al. 1999). They are a partial representation on the surface of what is stored in the subsurface, suggesting the possibility of a petroleum system.

The surveys developed for the indirect detection of microseepages use the effects that they cause in the environment (Fig.1). These include physical and chemical changes in soil and rocks and its effects on vegetation (Saunders et al. 1993, Schumacher 1996).

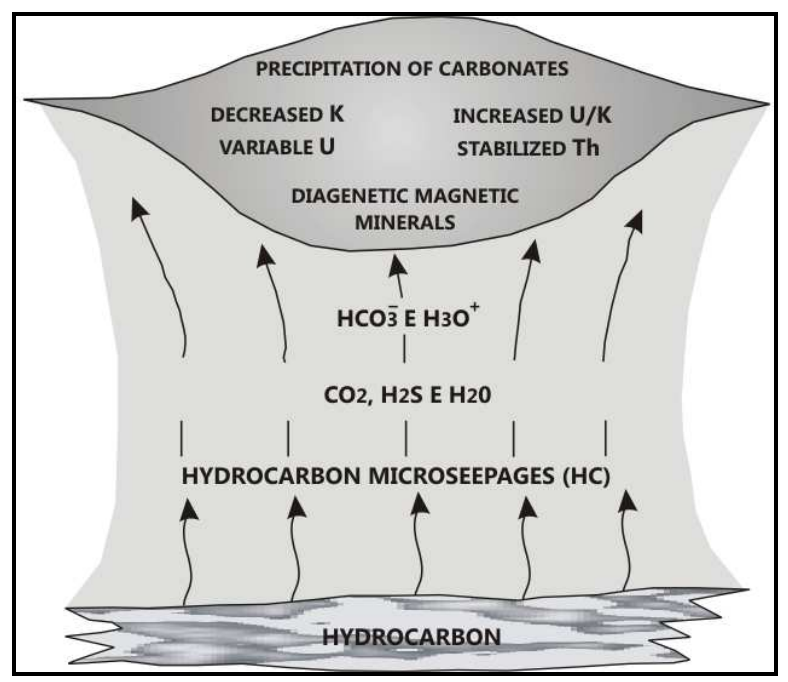

Figure 1 - Types of alterations in an area affected by hydrocarbons (Saunders et al. 1993, Saunders et al.1999), illustrating the variation of radioelement concentrations, whereas the thorium concentration stays stable.

Areas under the influence of microseepages provide the formation of reduction zones, where most of potassiumbearing minerals are destroyed and the production of hydronium ions replaces potassium ions. This process causes potassium depletion, whereas most thoriumbearing minerals stay stable and can be used as a lithological control to define the "ideal" potassium values. Therefore, the airborne gamma-ray spectrometric data were analyzed using a Th-normalized approach to detect low potassium values (Saunders et al. 1987, Pires 1995).

Uranium has dual behavior, because it can either precipitate as uraninite in reduction zones or be leached away in oxidizing zones; however, under microseepages influences, it has positive concentration when compared to the potassium concentration (El-Sadek 2002). Uranium 
can also have a significant noisy signal in radiometric data provided by the presence of radon in soil (Dickson \& Scott 1997), mainly where there is humidity, which can be strongly observed in alluviums and colluviums of the studied area. Therefore, the uranium products were not integrated with other results and will not be presented in this study.

The reduction condition also provides a higher concentration of magnetite, maghemite, and iron sulfides, called as micro-magnetic anomalies (Schumacher 1996). Therefore, the airborne magnetic data were analyzed to allow the detection of these micro-magnetic anomalies and to identify near-surface geological structures which allowed the percolation of gas to the surface.

In Brazil, the surveys for this type of application has been mostly based on orbital remote sensing data (Oliveira \& Crósta 1996, Souza Filho et al. 2008), whereas magnetometry and gamma-ray spectrometry have been recently considered (Lugão et al. 2009). Therefore, this study aims to present the results achieved with the use of high-resolution aerogeophysics, composed by gamma-ray spectrometry and magnetometry, in detection of microseepages and their relationship to the basin's structural framework, using the Petrobrás surface geochemistry as validation data.

\section{Study Area}

This study was developed in the San Francisco Basin, near and between the junction of Paracatu and San Francisco Rivers (MG), called Remanso do Fogo area.
This region has a significant amount of gas seepages (Fugita \& Clark Filho 2001), many of them along rivers, lakes and water wells, thus detected by the bubbles that it causes (Oliveira 1998). It also has a history of investigations carried out by Petrobrás since the 60's and stepped out since the 90's by the utilization of direct and indirect prospecting methods, such as surface geochemistry, well logs, geophysics and remote sensing. The 1-RF-1-MG well log was located in the studied area and provided information related to its stratigraphic profile, depth of the basin, and composition of the hydrocarbons.

The geologic scope of this study area is composed by the Bambuí Group - São Francisco Supergroup - and Sanfranciscana Basin (Fig.2).

Locally the basin is approximately 1800 meter deep, with a stratigraphic section that is composed, from the oldest to the newest unit, as follows: (i) Macaúbas Group, with sandstones and siltstones; (ii) Bambuí Group, with sandstones, siltstones, conglomerate, carbonates, claystones, diamictites and shales; and (iii) Sanfranciscana Basin, with sandstones and siltstones (Fugita \& Clark Filho 2001).

The surface of the area is dominated by recent sediments of Sanfranciscana Basin, and restricted to the southeast portion of the area there are sandstones, siltstones and carbonate levels from Bambuí Group outcrops.

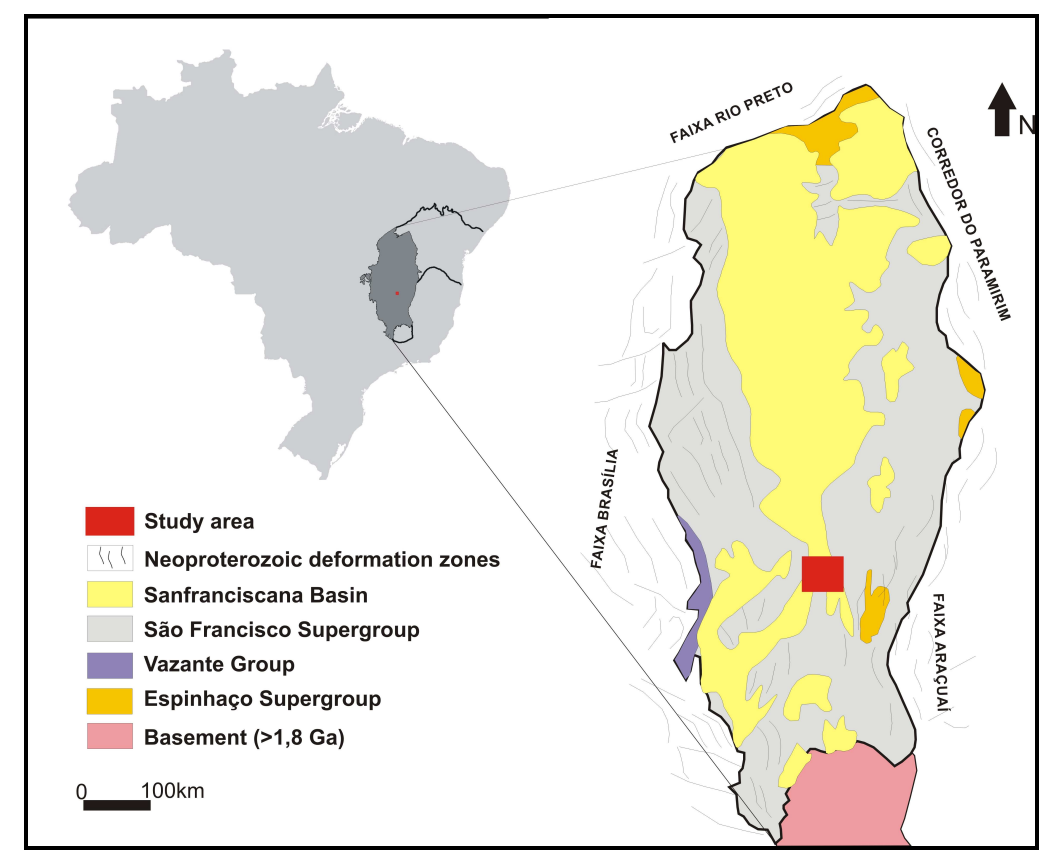

Figure 2 - Regional geologic features of the south portion of the São Francisco craton (Alkmim et al. 1993, Alkmim \& Martins-Neto 2001). The studied area is located in red, which includes in its surface: sediments, from the Sanfranciscana Basin, and Bambuí Group- São Francisco Supergroup. 


\section{Methodology}

This study used the airborne geophysical data from the San Francisco Project - ANP (Brazilian Petroleum National Agency), with line spacing of $500 \mathrm{~m}$ and flight height of $100 \mathrm{~m}$. The geochemical data was acquired by Petrobrás and it was made for this study as isoconcentration curves of light hydrocarbons in order to validate the geophysical results.

In order to apply the Th-normalization technique for the potassium analysis, the gamma-ray spectrometry database was separated according to different types of lithology present in the studied area. Regression analysis between $\mathrm{K}$ and $\mathrm{Th}$ values associated to each lithology was conducted. Regression equations were used to obtain "ideal" potassium values (Eq.1). Difference between ideal and original $\mathrm{K}$ concentration values yielded residual potassium estimates (Eq.2). Finally, the low residual potassium values were determined.

$$
\begin{gathered}
K_{i}=a+b{ }^{*} T h_{s} ; \\
K_{\text {resi }}=K_{S}-K_{i} ;
\end{gathered}
$$

(Equation 1)

(Equation 2)

Where $K_{i}$ is the "ideal" or "predicted" potassium value, $K_{S}$ and $T h_{S}$ are the original potassium and thorium values, and $K_{\text {resi }}$ is the residual potassium value.

The procedure used on the magnetic data enhanced the high frequency anomalies, looking for near-surface magnetic features. Therefore, most of the regional information was subtracted from the total magnetic field, resulting on the residual magnetic field. The second derivatives ( $D z$, Dy and $D x$ ) were made to produce the amplitude of analytic signal, and it was used to detect the shallower magnetic responses.

The results of $\mathrm{K}$ depletion and the amplitude of analytic signal represent near-surface products and they were integrated using fuzzy logic classification.

To observe magnetic lineaments from a specific depth range of the sedimentary section the horizontal gradient was produced from the subtraction between 1200 meter and 400 meter upward continuations.

\section{Results and discussion}

The Remanso do Fogo area is dominated by alluvial sediments and a relatively dense drainage network. These characteristics lead to difficulties in geological/structural mapping and identification of areas affected by the action of hydrocarbons. Therefore, the results achieved were based on suppressing most of the regional information and emphasizing local signatures.

Normally, in regions dominated by recent sediments and close to fluvial channels, potassium concentration displays already low average (Dickson \& Scott 1997). Because of this, the background suppressing procedure taken to each lithology unit was definitely the main key to find $\mathrm{K}$ local variations. The application of the Thnormalization technique allowed the detection of the lowest residual potassium values, reflecting local potassium depletion areas for each litho type. These values have a significant correspondence with the isoconcentration hydrocarbon curves and occurrences of gas in rivers and lakes (Fig.3).

The sampling made by the Petrobrás geochemical campaign was restricted to access routes and some of the detected potassium anomalies are located in areas that were not covered by this sampling and may indicate new microseepages. Moreover, this irregular distribution of the geochemical sampling causes common displacement errors in the iso-concentration curves, while the geophysical sampling displays a uniform distribution and may indicate more accurate positions for the hydrocarbon occurrences.

In the amplitude of the analytic signal, the east and south portion of the area presents most of all near surface magnetic signatures compared to the west portion. The magnetic lineaments with NW and EW directions have a significant spatial correlation with areas that have recorded occurrences of gas and potassium depletion. Probably, these features represent the shallower structures of this sedimentary basin portion, which may be controlling the passage of hydrocarbons. It is also observed the correspondence with the drainage flow changes, in NW and EW directions (Fig.4).

The application of fuzzy logic classification on the amplitude of analytic signal and potassium depletion products resulted in areas with high favorability for microseepages occurrences and indicated new prospective targets that were not observed by the other results.

The 1200 meter upward continuation has the predominance of deeper magnetic lineaments, while in 400 meter upward continuation is possible to detect some influences from the basement and mainly from the intrasedimentary features. Therefore, the magnetic lineaments which could be the passage of gases would be the intrasedimentary structures and, to enhance only them, it was made the horizontal gradient of the subtraction between these upward continuations. And, once more, the results of $\mathrm{K}$ depletion and the occurrences of gases displayed $\mathrm{a}$ good correlation with the intra-sedimentary features (Fig.4). It is also observed an interesting association between the drainage flow changes in NW and EW directions with the magnetic lineaments, which may be represented by shallow sedimentary structures that control this drainage flow as the gas passage.

Once more the suppression of regional contributions caused by deeper magnetic signatures was very important to observe near-surface lineaments and to correlate them with the gamma-ray spectrometry data. 


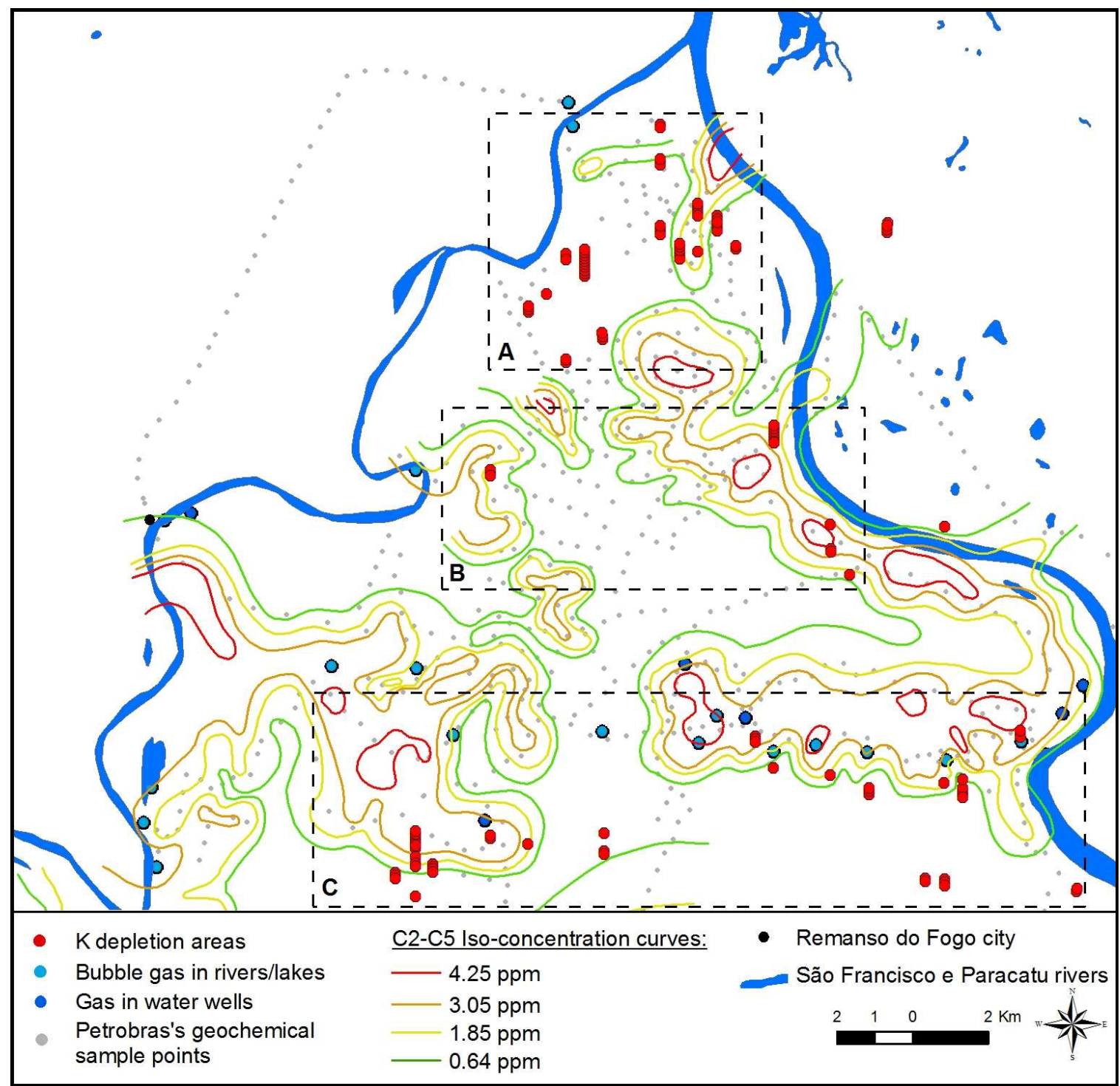

Figure 3 - Maps of iso-concentration curves of ethane to pentane (C2-C5). The illustration shows the sample points made by Petrobrás and registered occurrences of gas in water wells, rivers and lakes. Overlaid on the map, the residual potassium anomalies are exposed. They were separated in three main portions; A: on the right, the potassium anomalies have coincided with the iso-concentration curves and, on the left, the area occupied by the anomalies was not sampled by the geochemical campaign; B: most of the anomalies have correspondence with the geochemical data; $\mathrm{C}$ : on the right, the residual depletion anomalies have a significant spatial correspondence with the occurrences of gas and, on the left, the anomalies also have a correspondence with the curves, even though this area was poorly sampled. 


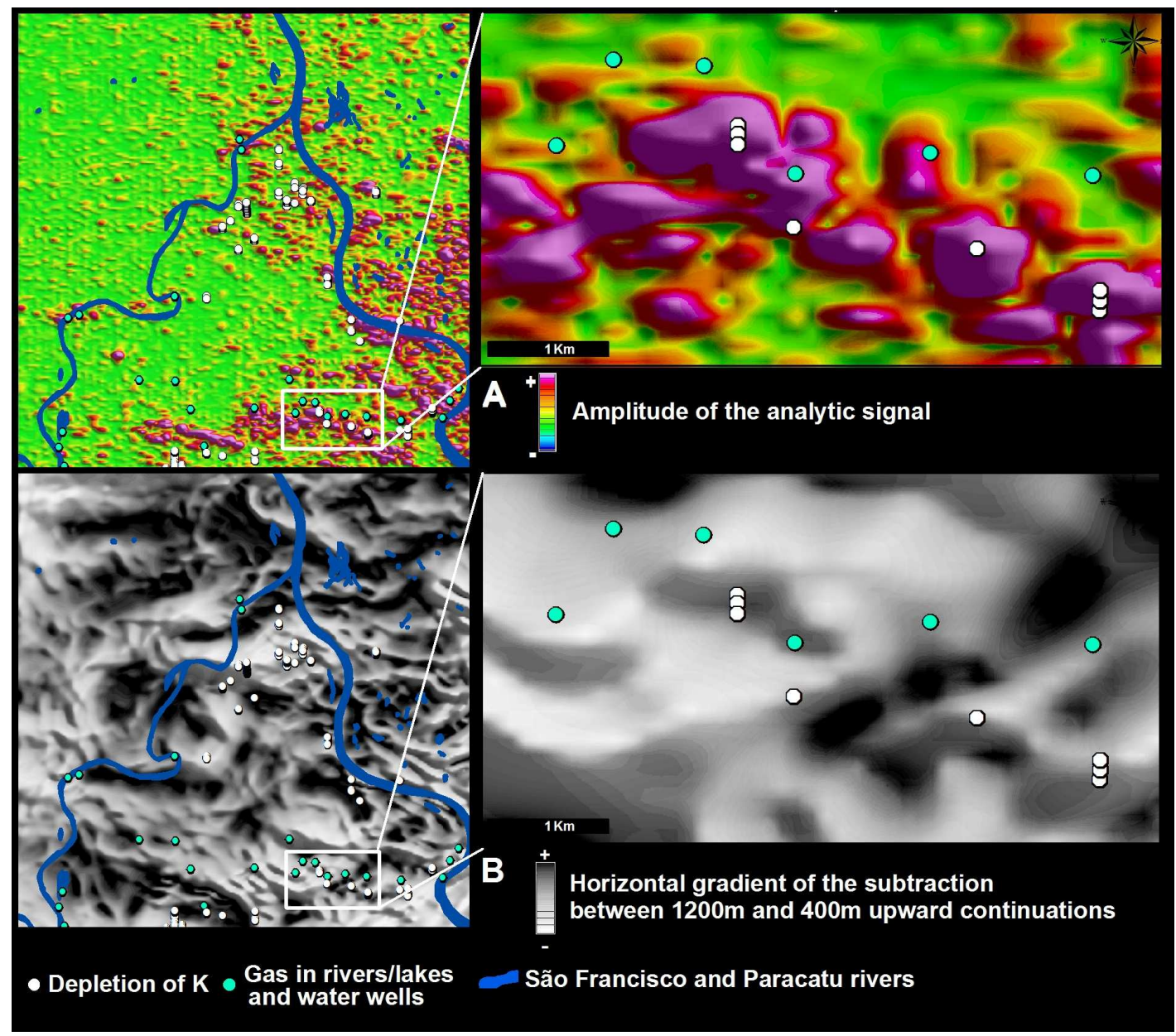

Figure 4 - A: Amplitude of the analytic signal showing the correspondence between near-surface magnetic signatures, potassium depletion values and registered occurrences of light hydrocarbons. B: This relationship is also observed in the horizontal gradient of the subtraction between $1200 \mathrm{~m}$ and $400 \mathrm{~m}$ upward continuations.

\section{Conclusions}

The thorium-normalized technique applied to the gammaray spectrometry data allowed the observation of the spatial distribution of residual potassium low concentration values, relative to their respective lithology. Despite the presence of alluvial sediments in a large proportion of the area, this method was very efficient, in the sense that most of the residual potassium values presented a significant validation by the geochemical data, while in locals where the geochemical sampling was not effective the other values may indicate new areas affected by hydrocarbon and more accurate positions for the microseepages already mapped.

The Remanso do Fogo area has a small set of structures mapped in the field, mainly because of a significant presence of recent sediments. However, in this study, the basin structural framework was observed and distinguished by shallower and deeper signatures from the magnetic data, using the amplitude of analytic signal and the subtraction of the upward continuations to 400 and 1200 meters. These features were interpreted as intra-sedimentary and basement structures and, some of the shallower lineaments had intercepted the residual potassium results and the geochemical data, suggesting that they are gas pathways.

The analysis of the geophysical data classified by the fuzzy logic and integrated with the geochemistry enabled the evaluation of possible sedimentary structures that the hydrocarbon gases use to reach the surface, in areas marked by the low residual potassium. It is possible to use these results in the selection of new targets in the exploration of gas and to better understand the functioning and viability of this possible petroleum system. 


\section{Acknowledgments}

We thank the contribution of Dr.Wilson de Oliveira; ANPBrazilian National Petroleum Agency for the permission to use geophysical data for academic purposes; CPRMGeological Survey of Brazil for providing the geological map of the region of Santa Fé - MG; LGA/UNB Laboratory of Applied Geophysics by disposing its infrastructure; and CAPES-Coordination for the Improvement of Higher Education, by granting scholarship to one of the authors

\section{References}

Alkmim, F.F., Brito Neves, B.B., Castro Alves, J.A., 1993. Arcabouço tectônico do Cráton do São Francisco - Uma Revisão. In: Dominguez, J.M.L.\& Misi, A. (Ed.), O Cráton do São Francisco. Salvador, SBG/Núcleo BA/SE, p.: 4562.

Alkmim, F.F \& Martins-Neto, M.A., 2001. A bacia intracratônica do São Francisco: Arcabouço estrutural e cenários evolutivos. In: Pinto, C.P. \& Martins-Neto, M. A. (Ed.) A Bacia do São Francisco. Geologia e Recursos Naturais. SBG/Núcleo MG, p.: 9-30.

Dickson, B.L. \& Scott, K.M., 1997. Interpretation of aerial gamma-ray surveys-adding the geochemical factors. AGSO Journal of Australian Geology \& Geophysics, 17 (2): 187-200.

El Sadek, M.A., 2002. Application of thorium-normalized airborne radio-spectrometric survey data of Wadi Araba area, North-eastern Desert, Egypt, as a guide to the recognition of probable subsurface petroleum accumulations. Applied Radiation and Isotopes, 57: 121130.

Fugita, A.M. \& Clark Filho, J.G., 2001. Recursos Energéticos da Bacia do São Francisco: Hidrocarbonetos Líquidos e Gasosos. In: Pinto, C.P. \& Martins-Neto, M. A. (Ed.), A Bacia do São Francisco. Geologia e Recursos Naturais. SBG/Núcleo MG, p.:265-284.

LeShack, L.A. \& Van Alstine, D.R., 2002. High-resolution Ground-magnetic (HRGM) and Radiometric Surveys for Hydrocarbon Exploration: Six Case Histories en Western Canada. In: Schumacher, D. \& LeShack, L.A. (Ed.), Surface Exploration Case Histories. Applications of Geochemistry, Magnetics, and Remote Sensing. A.A.P.G
Studies in Geology $N^{\circ} 48$ and SEG Geophysical References Series $N^{\circ} .11$, Tulsa, p.: 67-156

Lugão, P.P., Terra, E.F., Maia, M.T.P., Rocha, L.F., 2009.First Magnetic/Gamma Spectrometry Survey for Hydrocarbon Exploration in Brazil Identifies MicroSeepage Anomalies. 11th International Congress of the Brazilian Geophysical Society, 2009, Salvador.

Pires, A.C.B., 1995. Identificação geofísica de áreas de alteração hidrotermal, Crixás-Guarinos, Goiás. Rev.Bras.Geoc., 21(1):61-68.

Saunders. D.F., Terry. S. A., Thompson. C. K., 1987. Test of National Uranium Resource Evaluation gamma-ray spectral data in petroleum reconnaissance. Geophysics, 52:1547-1556.

Saunders, D.F., Burson, K.R., Branch, J.F., Thompson, C.K., 1993. Relation of thorium-normalized surface and aerial radiometric data to subsurface petroleum accumulations. Geophysics, 58(10):1417-1427.

Saunders, D.F., Burson, K.R., Thompson C.K., 1999. Model for hydrocarbon microseepage and related nearsurface alterations. A.A.P.G.Bull, 83: 170-185.

Schumacher, D., 1996. Hydrocarbon-induced alteration of soils and sediments, In: Schumacher, D. \& Abrams, M.A. (Ed.), Hydrocarbon Migration and its Near Surface Expression. A.A.P.G Memoir 66, p.: 71-89

Souza Filho, C.R., Augusto V., Oliveira W.J., Lammoglia T., 2008. Detecção de exsudações de hidrocarbonetos por geobotânica e sensoriamento remoto multi-temporal: estudo de caso no Remanso do Fogo (MG). Rev.Bras.Geoc., 38 (2-suplemento):228-243.

Oliveira, W.J. \& Crósta, A.P., 1996. Detection of hydrocarbon seepage in the São Francisco Basin, Brazil, through Landsat TM, soil geochemistry and airborne spectrometry data integration. Proccedings of the $17^{\text {th }}$ Thematic Conference and Workshops on Applied Geologic Remote Sensing, Las Vegas, Nevada, vol.1: 155-165.

Oliveira, W.J., 1998. Caracterização das Emanações gasosas de hidrocarbonetos na região do Remanso do Fogo (MG) através do uso integrado de sensoriamento remoto, geoquímica, geofísica, geologia estrutural e espectrometria de reflectância. Ph. D. Thesis, State University of Campinas, Brazil, 239p. 